\title{
Complex Regional Pain Syndrome After Herpes Zoster: A Case Report
}

\author{
Herpes Zoster Sonrası Kompleks Bölgesel Ağrı Sendromu: Olgu Sunumu \\ (1) Fulya Bakılan, (1) Sibel Ösken*, (1) Ayşe Ekim \\ Eskişehir State Hospital, Clinic of Physical Therapy and Rehabilitation, Eskişehir, Turkey \\ * Eskişehir Yunus Emre State Hospital, Clinic of Physical Therapy and Rehabilitation, Eskişehir, Turkey
}

\section{Abstract}

A 78-year-old male patient, diagnosed with herpes zoster infection, had color change, stiffness, swelling and burning pain on his left hand. Hand joints were painful, joint range of motion decreased and hyperpigmented, macular lesions on the left C5-C6 dermatome region was determined. After the medical and physical therapy programme, symptoms decreased significantly. Complex regional pain syndrome (CRPS) is a painful disorder with swelling, stiffness in joints, vascular instability, and dystrophic skin changes. Symptoms most commonly occur after trauma, stroke, surgery, myocardial infarction, fracture, cancer. In this case, an unusual cause of complex regional pain syndrome, herpes zoster, was reported. Only a few cases have been reported to date. In this case report, it is emphasized that CRPS can occur as a complication of many conditions. Early diagnosis and appropriate treatment lead to better outcomes.

Keywords: Complex regional pain syndrome, herpes zoster, rehabilitation

\section{Öz}

Herpes zoster enfeksiyonu tanılı 78 yaşında erkek hastanın sol elinde renk değişikliği, tutukluk, şişlik ve yanıcı ağıısı mevcuttu. El eklemleri ağrılı, eklem hareket açıkığı azalmış ve hiperpigmente, sol C5-C6 dermatomal bölgede maküler lezyonlar tespit edildi. Medikal ve fizik tedavi programı sonrası semptomlar anlamlı şekilde azaldı. Kompleks bölgesel ağrı sendromu (KBAS) şişlik, eklemlerde tutukluk, vasküler instabilite, distrofik deri değişiklikleriyle ağrılı bir bozukluktur. Semptomlar sıklıkla travma, inme, cerrahi, miyokard enfarktüs, kııı, kanser sonrası görülür. Bu olguda kompleks bölgesel ağrı sendromunun olağandışı bir nedeni olan herpes zoster bildirilmiştir. Bugüne kadar sadece birkaç olgu rapor edilmiştir. Bu olgu sunumunda KBAS'nin birçok durumun komplikasyonu olarak görülebileceği vurgulanmaktadır. Erken teşhis ve tedavi, olumlu sonuçlara yol açmaktadır.

Anahtar kelimeler: Kompleks bölgesel ağrı sendromu, herpes zoster, rehabilitasyon

\section{Introduction}

Complex regional pain syndrome (CRPS) (reflex sympathetic dystrophy) is a painful disorder that affecting the hands but also arms, legs and limbs. The clinical features are spontaneous pain, hyperalgesia, stiffness, impairment of motor function, swelling and autonomic abnormalities. Symptoms most commonly occur after trauma. Other causes include infection, stroke, surgery, myocardial infarction, fracture, cancer (1). Although herpes zoster was first described by Sudeck (2) as a complication in 1901, only a few reports of herpes zoster as the cause of this syndrome has been reported (3-7). We describe this case of a patient with CRPS features after an herpez zoster infection.

\section{Case Report}

A 78 years old male patient, with a vesicular rash that is limited to C4-C5-C6 dermatomes, was diagnosed with herpes zoster infection in dermatology clinic. The patient had been treated $3000 \mathrm{mg} /$ day valacyclovir for ten days. After ten days, swelling of the dorsum of the left hand and burning pain in the hand and fingers evolved gradually. The patient had gabapentin, tramadol and nonsteroidal anti-inflammatory drugs (NSAID) therapy, but symptoms increased. The patient was seen in our clinic three months later, with burning pain in the left hand and fingers, stiffness in the fingers, decrease of nail growth. He had no systemic disease. In physical examination, hyperpigmented, maculer lesions in on the left C5-6 dermatome, blue colored cold skin and dryness in on the hand, fragile nails were seen (Figure 1). The wrist, metacarpophalangeal, distal and proximal interphalangeal joints were painful and decreased range of motion were determined. All of the laboratory test values (hemogram, biochemistry, sedimentation, C-reactive protein, rheumatoid factor, thyrotrophin-stimulating hormone levels) were in normal limits, only 25 hidroxy vitamin D3 level was

Address for Correspondence/Yazıșma Adresi: Sibel Ösken MD, Eskişehir Yunus Emre State Hospital, Clinic of Physical Therapy and Rehabilitation, Eskişehir, Turkey Phone: +90 5368735080 E-mail: sibeltos@yahoo.com ORCID ID: orcid.org/0000-0003-2943-4833 Received/Geliş Tarihi: 06.01.2018 Accepted/Kabul Tarihi: 27.07.2018

${ }^{\circ}$ Copyright 2018 by the Turkish Osteoporosis Society Turkish Journal of Osteoporosis published by Galenos Yayınevi. 
$22 \mathrm{ng} / \mathrm{mL}$. Patchy osteoporosis were seen in the radiographs on the left hand (Figure 2). The patient was diagnosed as CPRS after herpes zoster and given Vitamin D3 1000 IU/per day, pentoxifylline $400 \mathrm{mg} /$ day, pregabalin $75 \mathrm{mg} /$ day, acemetacin $90 \mathrm{mg} /$ day. Physical therapy was planned for 30 sessions, which included contrast bath, left hand, wrist transcutaneous electrical nerve stimulation, stretching and strengthening exercise. Six weeks later, the complaints of the patients were markedly resolved and, dryness, blue color of skin were disappeared (Figure 3).

Written informed consent was obtained from the patient.

\section{Discussion}

Herpes zoster is a self-limiting disease, with pain quenching at the end of vesicular eruption in dermatomal distribution.

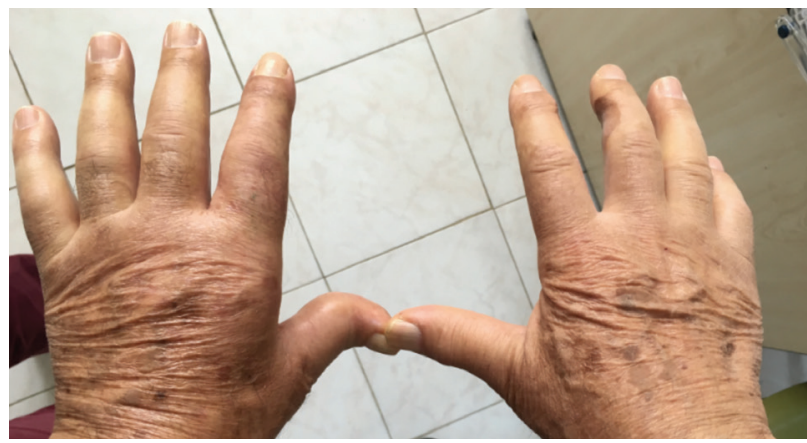

Figure 1. Hyperpigmented, maculer lesions in on the left C5-6 dermatome, blue colored cold skin and dryness in on the hand, fragile nails are seen

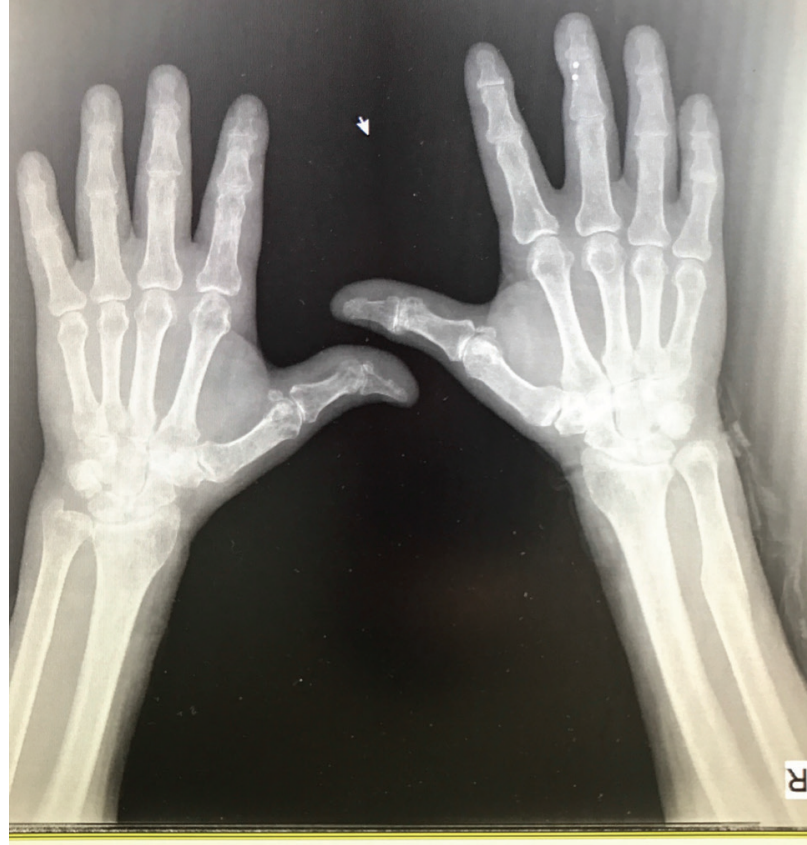

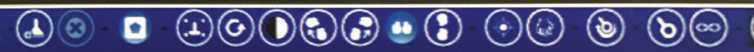

Figure 2. Patchy osteoporosis are seen in the radiographs on the left hand
Herpes zoster results from reactivation of latent varicellazoster virus within the sensory ganglia (8-10). The incidence and severity of herpes zoster increase with advancing age and immunodeficiency or cancer (11); more than half of all persons are older than 60 years. Also our patient was 78 years old, had no systemic disease. The most frequent debilitating complication is postherpetic neuralgia, a neuropathic pain syndrome that persists or develops after the dermatomal rash has healed $(9,10,12)$. Other neurologic complications are peripheral motor neuropathy, cranial nerve palsy, myelitis, encephalitis, cerebral thrombotic vasculopathy, acute polyradiculitis and aseptic meningitis $(13,14)$. CRPS is a rare complication and only a few reports have been described in the literature (3-7). A case was a 65 years woman with characteristic signs and symptoms of CRPS in the right upper limb. CRPS was appeared four weeks after a herpes zoster infection. Intranasal calcitonin and physiotherapy lead to progressive functional and pain improvements (3). Similarly to the previous case, a 64-year-old woman with CRPS in the right hand that appeared four weeks after she had a herpes zoster infection, had medical treatment (diclofenac sodium, deltacortril, gabapentin, and lansoprazole) and physical therapy. She achieved a progressive improvement with early diagnosis and treatment (4). In our patient, CRPS development time was shorter from above cases. Despite different treatment options, progressive improvements were obtained in all studies. Several hypothesis can explain the mechanism of herpes zoster in causing CRPS, the first mechanism is, herpes zoster causes intense pain. This initial afferent nociceptive stimulus can sensitize multiple sympathetic neurons, resulting sympathetic outflow. The second mechanism is secondary inflamation due to cytopathic changes of herpes zoster infection. The third mechanism is spontaneously abnormal synapses between the efferent sympathetic nerves and afferent sersory nerves due to herpes zoster infection (15-17). Specific criteria for the diagnosis of CPRS were adopted in 2013 as the new international standard by the International Association for the Study of Pain (Table 1) (18). A comprehensive, integrated multidisciplinary

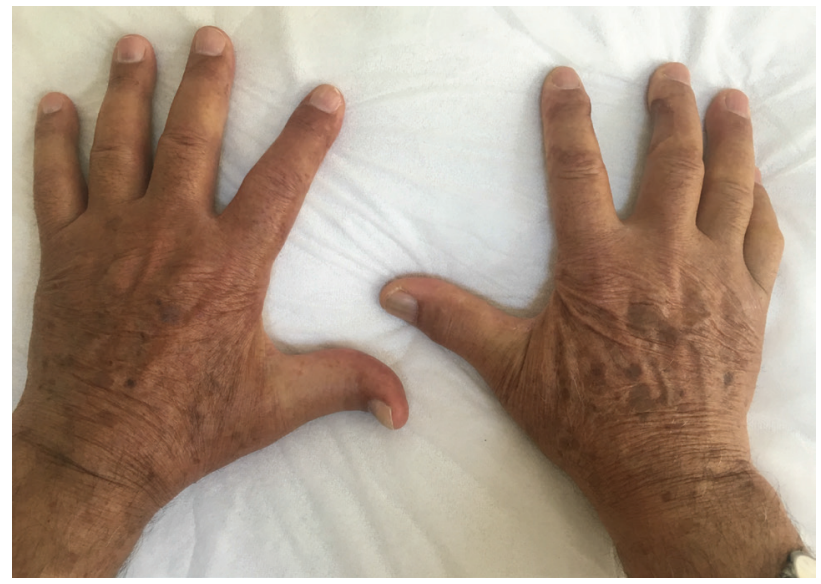

Figure 3. The hands of the patient six week after the treatment 
Table 1. Research diagnostic criteria for complex regional pain syndrome

Continuing pain, which is disproportionate to any inciting event

At least one symptom in three of the four following categories*:

Sensory: Hyperalgesia and/or allodynia

Vasomotor: Temperature asymmetry and/or skin color changes and/or skin color asymmetry

Sudomotor/edema: Edema and/or sweating changes and/or sweating asymmetry

Motor/trophic: Decreased range of motion and/or motor dysfunction (weakness, tremor, dystonia) and/or trophic changes

(hair, nails, skin)

At least one sign at time of evaluation in two or more of the following categories*:

Sensory: Evidence of hyperalgesia (to pinprick) and/or allodynia (to light touch or deep somatic pressure, or joint movement) Vasomotor: Evidence of temperature asymmetry and/or skin color changes and/or asymmetry

Sudomotor/edema: Evidence of edema and/or sweating changes and/or sweating asymmetry

Motor/trophic: Evidence of decreased range of motion and/or motor dysfunction (weakness, tremor, dystonia) and/or trophic changes (hair, nails, skin)

There is no other diagnosis that better explains the signs and symptoms

treatment that includes medical, psychological, and physical and occupational therapy is needed in the treatment of CPRS. Randomized trials suggest that steroids, NSAID, opioids, immun modulators, analgesic antidepressants, bisphosphonates, calcitonin, anticonvulsants, NMDA receptor antagonists, calcium channel blockers, block therapies, surgical sympathectomy, and spinal cord stimulation may be effective treatments $(18,19)$. In our patient, oral and topical NSAIDs, anticonvulsants, physical therapy and Pentoxifylline was used. Physical therapy increases patients range of motion, flexibility and strength (20). NSAIDs are used to treat pain plus inflammatory involvement in CRPS (21). Most often used as anticonvulsants, several have efficacy in neuropathic pain $(22,23)$. Also Pentoxifylline, a cytokine inhibitor, was used in our treatment to reverse nociceptive sensitization and vascular abnormalities (24). It is clinically accepted that early diagnose and treatment in CRPS will lead to better outcomes. Also our patient,showed a progressive improvement with early medical treatment and physical therapy. Although CPRS is a self limited clinical course in most cases, some patients may progress for years leading a major functional disability of the affected extremity. The early management of this clinical entity is very important in daily clinical practice.

\section{Ethics}

Informed Consent: Written informed consent was obtained from the patient.

Peer-review: Externally and internally peer-reviewed.

\section{Authorship Contributions}

Surgical and Medical Practices: A.E., F.B., Concept: A.E., F.B., S.Ö., Design: A.E., F.B., S.Ö., Data Collection or Processing: F.B., Analysis or Interpretation: F.B., S.Ö., Literature Search: F.B., Writing: F.B., S.Ö.

Conflict of Interest: No conflict of interest was declared by the authors.

Financial Disclosure: The authors declared that this study received no financial support.

\section{References}

1. Wasner G, Backonja MM, Baron R. Traumatic neuralgias: complex regional pain syndromes (reflex sympathetic dystrophy and causalgia): clinical characteristics, pathophysiological mechanisms and therapy. Neurol Clin 1998;16:851-68.

2. Sudeck P. Über die akute (reflektorische Knochenatrophie nach Entzündungen und Verletzungen an den Extremitäten und ihre klinishen Erscheinungen). Fortschr Geb Roentgenstr 1901;5:277-93.

3. Minami CSH, Costa MD, Antonio SF, Chadade WH. Distrofia simpática reflexa pós herpes zoster. Rev Bras Reumatol 2004;44:301-4.

4. Öztop P, Coşar Saracgil SN, Ümit Yemişci O, Üre Varol RS. Complex regional pain syndrome associated with herpes zoster: a case report. Turk J Rheumato 2011;26:254-7.

5. Visitsunthorn $U$, Prete P. Reflex sympathetic dystrophy of the lower extremity: a complication of herpes zoster with dramatic response to propanolol. West J Med 1981;135:62-6.

6. Grosslight KR, Rowlingson JC, Boaden RW. Herpes zoster and reflex sympathetic dystrophy. Anesth Analg 1986;65:309-11.

7. Foster O, Askaria A, Lanham J, Perry D. Algoneurodystrophy following herpes zoster. Postgrad Med J 1989;65:478-80.

8. Gnann JW Jr, Whitley RJ. Clinical practice. Herpes zoster. N Engl J Med 2002;347:340-6.

9. Hope-Simpson RE. The nature of herpes zoster: a long-term study and a new hypothesis. Proc R Soc Med 1965;58:9-20.

10. Weller TH. Varicella and herpes zoster. Changing concepts of the natural history, control, and importance of a not-so-benign virus. N Engl J Med 1983;309:1434-40.

11. Wood MJ. Current experience with antiviral therapy for acute herpes zoster. Ann Neurol 1994;35(Suppl):65-8.

12. Oxman MN. Clinical manifestations of herpes zoster. In: Arvin AM, Gershon AA, editors. Varicella zoster virus: virology and clinical management. Cambridge, England: Cambridge University Press; 2000. p. 246-75.

13. Elliot KJ. Other neurological complications of herpes zoster and their management. Ann Neurol 1994;35(Suppl):57-61.

14. Flamholc L. Neurological complications in herpes zoster. Scans J Infect Dis Suppl 1996;100:35-40.

15. Kozin F. Reflex sympathetic dystrophy syndrome: a review. Clin Exp Rheumatol 1992;10:401-9.

16. Roberts WJ. A hypothesis on the physiological basis for causalgia and related pains. Pain 1986;24:297-311.

17. Ecker A. Pathogenesis of reflex sympathetic dystrophy. Arch Neurol 1989;46:482.

18. Harden RN, Oaklander AL, Burton AW, Perez RS, Richardson K, Swan M, et al. Complex Regional Pain Syndrome; practical diagnostic and treatment guidelines, 4th edition. Pain Med 2013;14:180-229.

19. Harden RN, Swan M, King A, Costa B, Barthel J. Treatment of complex regional pain syndrome: functional restoration. Clin J Pain 2006;22:420-4. 
20. Rho RH, Brewer RP, Lamer TJ, Wilson PR. Complex regional pain syndrome. Mayo Clin Proc 2002;77:174-80.

21. Van der Laan L, Veldman P, Goris RJ. Severe complications of reflex sympathetic dystrophy: Infection, ulcers, chronic edema, dystonia, myoclonus. Arch Phys Med Rehabil 1998;79:424-9.

22. Sindrup $\mathrm{SH}$, Jensen TS. Efficacy of pharmacological treatments of neuropathic pain: an update and effect related to mechanism of drug action. Pain 1999;83:389-400.
23. Collins SL, Moore RA, McQuay HJ, Wiffen P. Antidepressants and anticonvulsants for diabetic neuropathy and postherpetic neuralgia: A quantitative systematic review. J Pain Symptom Manage 2000;20:449-58.

24. Sabsovich I, Guo TZ, Wei T, Zhao, R, Li X, Clark DJ, et al. TNF signaling contributes to the development of nociceptive sensitization in a tibia fracture model of complex regional pain syndrome type I. Pain 2008;137:507-19. 